\title{
Hereditary Glomangioma
}

National Cancer Institute

\section{Source}

National Cancer Institute. Hereditary Glomangioma. NCI Thesaurus. Code C5350.

A familial glomus tumor. 